\title{
Anomalias da política de segurança pública: a prática da catação e o policiamento ${ }^{1}$
}

Anomalies of Public Security Policy: The Practice of Catação and Policing

\author{
Daniel Chaves de Brito ${ }^{1}$, Jaime Luiz Cunha de Souza ${ }^{2}$ e \\ Daguinete Maria Chaves de Brito ${ }^{3}$
}

1 Doutor pelo NAEA/UFPA e Professor da Faculdade de Ciências Sociais/UFPA. E-mail: dnbrito@ufpa.br

2 Doutor pelo PPGCS e Professor do PPGDSMC e da Faculdade de Ciências Sociais/UFPA. E-mail: - jaimecunha@ufpa.br

3 Doutora pelo PPGCS e professora da do curso de Geografia/UNIFAP, Brasil. E-mail: dagnete@uol.com.br

RESUM 0: Dentre as principais políticas públicas encontra-se as políticas públicas de segurança, que comporta em seu bojo a formação do agente público denominado de policial militar e entre a formação desse agente e sua efetiva atuação na prestação do serviço de segurança pública existe uma enorme dificuldade para preservar os padrões de legalidade na atuação do agente público. Embora existam práticas policiais ilegais, como por exemplo, o arrego ou o bico, aqui queremos destacar a prática da catação. 0 objetivo deste trabalho é apresentar a lógica de funcionamento, a formação dos policiais nas redes de catação e estabelecer a diferença desta prática perante outras. A catação constitui um pagamento rotineiro por comerciantes da periferia das cidades, que pode ser mensal ou semanal, em dinheiro ou mesmo em mercadorias, para que a presença da polícia seja ostensiva nesses locais. Embora o foco seja essa prática nela podemos encontrar uma série de nuances de um patrimonialismo, em que o policial privatiza o serviço da polícia em seu benefício e de quem Ihe paga.

Palavras-Chaves: Policiamento. Segurança Pública. Práticas Policiais

\begin{abstract}
Among the main public policies are public security policies, which include the formation of the public agent called the military police and between the training of this agent and his effective performance in the provision of public security service there is a huge difficulty to preserve the standards of legality in the performance of the public agent. Although there are illegal police practices, for example, the bar or the beak, here we would like to highlight the practice of hunting. The objective of this work is to present the logic of operation, the training of police officers in the catchment networks and to establish the difference between this practice and others. The tipping is a routine payment by merchants on the outskirts of cities, which can be monthly or weekly, in cash or even in merchandise, so that the presence of the police is ostentatious in these places. Although the focus is this practice in it we can find a series of nuances of a patrimonialism, in which the policeman privatizes the service of the police in his benefit and of who pays to him.
\end{abstract}

Sumário: 1 Introdução; 2 Os desafios ambivalentes do oficial: da aceitação à catação; 3 A incorporação dos praças e as ambiguidades da lealdade diante dos esquemas; 4 A confiança como critério de aceitação; 5 Considerações finais; Referências.

\footnotetext{
${ }^{1}$ Trabalho elaborado com apoio da CNPq.
}

Planeta Amazônia: Revista Internacional de Direito Ambiental e Políticas Públicas 
Agente se sente traído (...) eu sempre fui leal, sempre fui fiel. Nunca atrasei. Todo santo mês eu trouxe aqui pro gabinete os 7 mil reais (...) Nunca falhei. Sou um cara fiel, leal (SOARES, PIM ENTEL \& BATISTA, 2005, p.331)

\section{INTRODUÇÃO}

Entre a formação dos policiais e sua efetiva atuação na prestação do serviço de segurança pública, existe uma ambivalência no contexto da inserção nas unidades operacionais, este é um universo ladeado pelas doutrinas e teorias escolares e o saber fazer das ruas, do cotidiano. Decidir entre práticas policiais ilegais, como, por exemplo, o arrego ou o bico ou seguir as normas e regras do trabalho legalmente definido é uma espécie de fardo que cai sobre os ombros dos policiais em qualquer nível.

Neste trabalho, estamos apresentando uma modalidade de prática policial ilegal, que possui características ambíguas e que é definida pelos próprios policiais como catação, que um pagamento rotineiro por comerciantes da periferia dos núcleos urbanos, que pode ser mensal ou semanal, em dinheiro ou em mercadorias, para que a presença da polícia seja ostensiva nesses espaços. Em muitos casos ela se materializa na forma de presentes, de ajuda ao reconhecimento do trabalho do policial. É um prêmio por parte de quem presenteia para alguém que ganha tão pouco para ariscar a própria vida. Assim essa prática constitui suas ambiguidades.

O objetivo deste trabalho é apresentar os conflitos decorrentes da incorporação de novos policiais no policiamento de rua e seu contato com a prática da catação; apresentar-seão três pontos deste processo: a inserção dos oficiais e dos praças, a base de sustentação da prática e o código de confiança. 0 material que serviu de base para a análise foram entrevistas realizadas em uma unidade operacional de policiamento ostensivo, por meio das quais foi possível traçar uma linha de apresentação e interpretação de uma prática submersa ou postada no cotidiano das atividades do policiamento.

Para efeitos deste trabalho, a catação será entendida como um tipo de corrupção operacional, isto é, um ato de abuso de autoridade, uma vez que quem o comete tira vantagem de sua posição e do poder que the é outorgado pelo pode público e sociedade (NEWBURN, 1999; URUEÑA, 2001). Assim, o fato de um policial aceitar um café ou outro bem ou serviço pelo qual normalmente deveria pagar não constitui um fato ilícito, mas bem poderia ser considerado um ato de corrupção se essa gratuidade gera algum tipo de compromisso com seu provedor.

É conveniente salientar que a distinção entre subornos e gratuidades está separada por uma tênue linha que deve ser definida na prática como um suborno que tem uma magnitude significativa e geralmente é proporcional ao serviço ou favor requerido e sua motivação é corromper a autoridade. Enquanto que as gratuidades, ao contrário, tendem a ser mais simbólicas e nada pode implicar, ao menos inicialmente, que uma gratuidade entregue a um polícia que tenha a intenção de ter alguma influência sobre sua atuação como policial. 


\section{OS DESAFIOS AM BIVALENTES DO OFICIAL: DA ACEITAÇÃO À CATAÇÃO}

Com a conclusão do Curso de Formação de Oficiais (CFO), após três intensos anos de treinamento e estudos teóricos, um período de dedicação integral na Academia de Polícia Militar (APM), inicia a carreira policial dos novos aspirantes a oficiais. Tudo começa com a incorporação nas unidades da Policia Militar para o período de estágio probatório representado pelo tempo mínimo de seis meses em que dura o aspirantado.

Essa posição inicial da vida profissional é muito importante, pois é algo como um limbo. Acima dele, estão todos os oficiais superiores e abaixo estão todos os praças. Aqui começa uma luta. Enquanto, por um lado, ele deve se posicionar para galgar as promoções que 0 levarão até coronel, por outro lado precisa desenvolver estratégias de aceitação e obediência. 0 desafio é conquistar a confiança dos oficiais superiores e a aceitação dos subordinados.

M esmo tendo sido formados para comandar, gerenciar, ser a cabeça pensante da instituição ao longo da carreira, os aspiras ${ }^{2}$ chegam às unidades operacionais quase sem experiência da prática de comando e passam a trabalhar comandando praças com mais anos de polícia (normalmente entre 10 a 15 anos de serviço).

Esse encontro gera insegurança e um bom grau de desconfiança entre eles. Além da insegurança, também é estabelecido o confronto entre o velho conhecimento prático dos praças (associado ao conservador), e o novo conhecimento teórico dos aspiras (associado ao inovador). Aqui é o momento crucial, em que cada parte defende teses, procedimentos e ideais para 0 atendimento de ocorrências.

Ao chegar ao batalhão, entretanto, 0 aspirante começa a perceber que essa rígida separação teórica entre os círculos hierárquicos pode ser subvertida/transposta na prática. $\mathrm{Na}$ verdade, ele irá se deparar com uma realidade bem diferente desse quadro legalmente composto por barreiras aparentemente intransponíveis. A constatação dessa subversão se dará quando ele iniciar o estágio probatório na atividade de policiamento de rua.

A realidade do policiamento ostensivo vai colocar sob o domínio da ambivalência todos os conhecimentos teóricos e uma dura convicção surgirá: os subordinados hierarquicamente, os praças, dominam um saber fazer que não está exposto em nenhuma cartilha doutrinária. É preciso incorporar a cultura subjacente, não escrita, do policiamento.

Uma primeira experiência de resistência, ainda que seja de forma velada, parte de alguns policiais graduados (sargentos e cabos), que exercem a função de comandantes de viaturas e, com vários anos de serviço, mas, hierarquicamente subordinados, resistem em obedecer a ordens dos aspirantes porque são novatos na atividade policial e sem experiência de comando e de atendimento de ocorrências, principalmente as que apresentam riscos de evoluir para situações mais graves.

Esse confronto inicial se dará porque os policiais veteranos precisam saber qual o posi-

\footnotetext{
${ }^{2}$ A invocação pelo imperativo aspira é apenas para deixar explicito ao que está chegando a condição dele no processo. Resolvemos adotar essa terminologia porque na pesquisa ficou claro que essa é uma forma de estereótipo usado pelos oficiais de maior grau hierárquico, em virtude de ser considerado um estagiário, que necessita adquirir certo grau de experiência para se tornar oficial, apesar de já possuir as mesmas atribuições e responsabilidades do tenente.
}

Planeta Amazônia: Revista Internacional de Direito Ambiental e Políticas Públicas 
cionamento dos aspiras quanto à aceitação/participação ou não nos esquemas da catação. Essas informações são importantes, pois delas a equipe depende para adotar as estratégias de resistência, no caso de não aceitação, ou de inclusão, caso haja a concordância. Para essa abordagem, alguém com muito jeitinho será encarregado de sondá-lo e depois informar aos demais membros da equipe acerca da posição dele para a tomada de decisão. A seguir um exemplo de como se processa essa abordagem.

Eu posso Ihe contar uma experiência que aconteceu comigo no [...] Batalhão, que era justamente o período de estágio, porque a gente veio pra cá, nós éramos três pro [...] e fizemos estágio em determinadas áreas de policiamento. Então, eu lembro que era aniversário do Batalhão. Eu tava assumindo de interativo da [...] Zpol na viatura [...]. Entrei na viatura, falei "bom dia" pro cabo que tava comigo. Ele disse: "Bom dia, chefe. Tudo bem? Chefe, eu posso lhe perguntar uma coisa?" Ele não perguntou nem 0 meu nome. "Meu chefe, qual é a sua opinião a respeito dos patrões?" (pessoas que pagam para a guarnição fazer rondas nos Pontos Básicos, próximo aos seus pontos comerciais ou fábricas). Aí eu: "Como é?" "É, dos patrões." Aí eu fui olhar. Aí eu comecei né, trinta minutos, quarenta e cinco minutos de: "Eu sou totalmente contra, por isso, por isso, por isso, por aquilo." "M eu chefe, muito bonito isso que o senhor falou pra mim, mas eu posso lhe falar uma coisa?" Aí eu: "Pode falar." "O senhor não vai ter motorista pro senhor." Eu falei: "como assim, não?" "O senhor vai ver. Aguarde e confira. 0 senhor tá vendo aqui? 0 senhor, a gente passa aqui em determinado lugar e só faz isso aqui ó (aciona a buzina da viatura), cinco reais. Se a gente passar em determinado lugar e só faz isso aqui ó (aciona a sirene da viatura), dez reais." "Mas eu não tenho essa postura, Fulano." "Mas, meu chefe, o senhor tá vendo ali, aquela viatura que vai bem ali na frente?" "Sim, é do tenente. E aí?" "Ele tá pegando o que era a sua cota." Eu falei: "Tá bom pô, mas ele é o tenente. Ele, é a postura dele. A minha postura é essa." Ele falou: "É, meu chefe. Então, é como eu tô Ihe falando" Passados dois, três serviços o motorista que tava escalado comigo, o sargento Fulano mandou tirar porque ele disse que ele não era motorista e tal. Fui procurar um motorista. "Fulano". "M eu chefe, tô sem carteira." "Mas tu não tá de motorista da nove meia?" "Não, meu chefe, mas a minha carteira tá vencida. Tá aqui." Aí eu peguei a carteira: "Pô, é mesmo, tá vencida, né. Pô, então tu não pode dirigir a viatura. Tu vai pro trailer." "Não, meu chefe, mas lá dá pra eu dirigir porque eu já conheço a área." Eu falei: "não, se tu não vai dirigir pra mim, tu não vai dirigir pra ninguém e tu vai pro trailer e eu vou botar outro motorista aí." Aí ele já se mordeu. Ficou com raiva, sabe? Mas ficou no trailer doze horas. Aí cheguei com o sargento: "sargento, tu vai dirigir pra mim." "Não, meu chefe, eu tô sem óculos. Porque não sei o quê e tal." Aí eu falei: "não, mas tu diriges na "manha" e tal. A gente vai levando na manha as doze horas." Aí é que eu já comecei a conversar. Senão, eu ia ter que... Aí eu cheguei lá com o tenente e falei: "Tenente, pô, o pessoal não quer dirigir." Aí ele disse, pegou assim e deu uma franzida na testa e abriu a mão e falou assim: "Tá vendo só" Aí eu fiquei assim "égua!" (expressão tipicamente paraense), mas desenrolei um motorista pra mim. (Tenente com 5 anos de serviço)

Aqui se percebe claramente o comprometimento do tenente com os esquemas existentes. Ele, que é o superior responsável pela orientação do aspirante, já demonstra qual a sua forma de trabalhar. Por isso, o aspira não encontra qualquer apoio ao se dirigir ao supe-

Planeta Amazônia: Revista Internacional de Direito Ambiental e Políticas Públicas 
rior, avaliador e orientador acerca da recusa dos policiais em dirigir a viatura que ele comanda. Isso porque, ao ser interpelado sobre sua opinião e, portanto, sua atitude diante da catação, aqui materializada pelas figuras do patrão (comerciante) e do empregado (policial), 0 aspira se posiciona contrário a essa prática que é tolerada por muitos oficiais e compartilhada por outros tantos, inclusive pelo tenente que aparece no depoimento acima.

Observa-se que, em uma única abordagem, o policial antigão ${ }^{3}$ apresenta ao aspira todo o esquema de catação estabelecido na Zona de Policiamento ${ }^{4}$ (ZPol) em que ele estava sendo empregado. Essa apresentação, não é sem intenção. 0 motorista é o encarregado de sondar 0 aspirante para, de posse da sua posição a respeito da prática da catação, informar aos demais e, assim, decidirem sobre a aceitação ou não do aspirante. Como o oficial é legitimamente superior dos policiais com os quais está trabalhando, estes não podem solicitar a saída da equipe, mas adotam a estratégia de dificultar o desenvolvimento do serviço a partir de então, a começar pela recusa de todos os motoristas em dirigir a viatura, como vimos no depoimento do tenente.

Em casos como este, de recusa de participação em esquemas ilícitos, o aspira precisa encontrar outras estratégias de aproximação da equipe com a qual vai trabalhar. Uma delas é 0 desempenho no atendimento das ocorrências. A seriedade e a forma de atendimento poderão conduzir o aspirante a uma posição de liderança e, por conseguinte, de respeito frente aos subordinados que, mesmo não aceitando sua posição de refutação aos esquemas, o aceitarão por outro lado, pela sua atuação. Nesta situação, como fica demonstrado na fala do oficial a seguir, para escapar da conivência direta com práticas ilícitas, é necessário mobilizar a consciência do policial para a questão da família, pois o direito enquanto parâmetros de policiamento não tem valor, nem na prática e nem cultura policial.

Taí o [soldado] Fulano [motorista da viatura], a minha preleção é praticamente a mesma desde aspirante. Eu toco em quatro pontos que eu acho que é fundamental pro serviço sair sem alteração. Primeiro, e aí, muitas das vezes eu falo até veementemente e os policiais, às vezes, ficam constrangidos. Primeiro, a segurança em toda e qualquer abordagem, que é fundamental. Se o policial não tiver segurança, não der a segurança pra ele, não vai poder dar segurança a outra pessoa. Proporcionalidade no uso da força. A força nem além e nem aquém da necessária. Legalidade nas ações. Prisões em flagrante delito e mediante mandado judicial. Prisões pra averiguações a gente sabe que ela é irregular, etc. etc. E, por fim, é um ponto que eu sempre costumo tocar a questão da ética no policiamento né, policial catando [...]. Então, eu sempre costumava tentar [...] jogar o policial pra próximo dele, não adianta eu falar aqui do direito, ordenamento etc. Eu tenho que aproximar o fato do policial. Quando eu consigo é, demonstrar pra ele que a postura dele é errada e que as consequências poderão ser bem próximas da família do policial [...] Mas eu acho que dói bem mais pra ele é ver a família dele ter que ir num lugar daquele visitá-lo, né. Num final de

\footnotetext{
${ }^{3}$ Antigão é o termo usado para destacar os membros da corporação com mais tempo de atividade, mas este termo vem carregado de nuances simbólicas. Entre os policiais, esta posição é sinônimo de autoridade, de experiência e de respeito e, em muitos casos, de inversão de hierarquia.

${ }^{4}$ Uma análise da criação das Zonas de Policiamento (Polícia Militar) e das Seccionais Urbanas (Polícia Civil) como política de integração do sistema de segurança pública do Estado do Pará pode ser encontrada em Oliveira Neto (2004).
}

Planeta Amazônia: Revista Internacional de Direito Ambiental e Políticas Públicas 
semana sim e outro não, né [...] Enfim, das brincadeiras, que isso é normal, que acontece. Então [...] eu sempre costumo aproximar essas relações do policial pra que ele entenda que a postura dele hoje, se ele ir numa boca de fumo pegar dinheiro do traficante, pode ser que esse mesmo traficante dois, três dias depois, esteja assaltando a esposa do policial, a filha dele [...]. Então, eu sempre procuro aproximar isso daquilo que o cara possa ver. Porque não adianta eu falar do direito, que vai causar isso, que vai causar, não. Eu sempre procuro, o cara tem que aproximar da realidade do policial. Porque se ele não aproximar, vai entrar por um ouvido, vai sair pelo outro e ele não vai escutar. (Tenente com 5 anos de serviço)

$\mathrm{Na}$ busca pela aquisição de aceitação, o aspirante-a-oficial procura se aproximar dos praças (soldados, cabos e sargentos), colocando-se numa condição de respeito e de valorização pela experiência dos subordinados mais antigos. Essa lógica se repete de forma ainda mais profunda na relação entre soldados novatos e sargentos (antigos). Porém, no caso dos oficiais, essa relação implica num teste de fogo, pois a todo tempo os praças (subalternos) estão testando a capacidade e a conduta de seus superiores (CARUSO, 2004). Algumas vezes, o teste é realizado sem que ele perceba que está sendo posto à prova, conforme veremos a seguir:

Os motoristas que passaram pela gente, com a gente, no caso, de interativo, se eles tinham essa prática, pelo menos, enquanto assumiam a função de motorista do interativo nenhum chegou comigo: "Olha, tenente, pô, tem uma coisa aqui e tal...". Não, nenhum. Nenhum chegou assim. M esmo das guarnições. Lógico, se fizeram, fizeram e eu não percebi. [...] até é um fato que... O policial veio da ROTAM. Ele era cabo da ROTAM. A gente encontrou um carro dum patrão dele, lá da..., que ele tirava bico, lá na [...]. Ele falou: "Olha, meu chefe, é o seguinte. Não tô insinuando nada pro senhor, mas quando o senhor chegar aqui, eu já avisei pra ele que o carro dele foi encontrado. Tá aqui, ele tá vindo pra cá. 0 senhor vai ver que ele vai Ihe oferecer alguma coisa. O senhor não vai nem precisar pedir. Ele vai, ele vai Ihe oferecer." Aí o cara chegou lá. Tá, beleza! Puxou cem reais. "Não, tenente, tá aqui. Muito obrigado por..." Isso aqui, não foi só aqui que aconteceu. Isso aconteceu também em Mosqueiro. "Tá aqui pro lanche dos senhores". "M eu senhor, o senhor me desculpe, mas eu não vou aceitar. Pra mim seria bem mais interessante aqui, que senhor pegasse esses seus cem reais, o senhor pudesse colocar uma notinha lá no jornal e botasse lá: "Guarnição de [...] (local da pesquisa) trabalha com eficiência, encontrou meu carro etecetera e tal, tá de parabéns os policiais do Batalhão" [...], porque aí o senhor vai tá fazendo o benefício pro todo [...]. O cara ficou olhando assim pra mim é, por um lado, assustado pela postura que eu tomei porque pra ele era líquido e certo que eu ia aceitar, mas por outro, espantado com a postura do encaminhamento que eu tinha falado pra ele dar pro dinheiro. 0 cabo, ele ficou olhando assim, mas também não questionou, não, não falou nada sobre a minha postura. Não. "Pô, meu chefe, ele vai dar. Agora, o senhor aceita se o senhor quiser." (Tenente com 5 anos de serviço)

0 teste a que 0 aspirante foi submetido atua em dois lados. No primeiro, o policial com quem ele trabalhava que, certamente, estranhou seu comportamento, porque em situações como estas, em que o cidadão oferece a recompensa, a conduta de aceitá-la não é considera- 
da ilícita por grande parte dos policiais já que ele não está pedindo, mas é o cidadão que está dando. No segundo, é o próprio cidadão quem está testando-o, já que todos os policiais esperam receber alguma coisa quando recuperam um bem roubado ou furtado e ligam para 0 proprietário para informar acerca da recuperação, como fez 0 cabo, ligando para o patrão, comunicando a recuperação do automóvel.

No que diz respeito à desconfiança dos policiais antigões em relação aos novinhos $\mathrm{s}^{5} \mathrm{Mi}$ randa (2009) afirma que ela é mais grave quando o novato é superior hierárquico do antigão, como é o caso do aspirante. Este, apesar de novato, é mais antigo na hierarquia militar do que todos os demais integrantes da equipe de serviço a qual vai comandar. Além disso, se os seus métodos de trabalho, em princípio, não corresponderem à forma de trabalho a que os antigões estão habituados, essa diferença irá colocar em conflito os dois grupos no campo policial: oficiais e praças.

Vale assinalar que essa divisão, que gera os conflitos, começa a ser alimentada no curso de formação. E ela dará a tônica das relações entre os aspiras e os antigões desde os primeiros contatos no cotidiano de serviço que se iniciam nos estágios do curso de formação. É, portanto, nesse ambiente que os aspirantes irão procurar impor a sua forma de trabalhar e modificar a dos antigões que, certamente, resistirão a essas tentativas, conforme apresenta a fala a seguir:

P - Qual é a experiência de um aluno oficial estagiar de comandante da viatura? Não dá assim certo nervoso de começar, de chegar e de já trabalhar com um antigão experiente?

$R$ - É porque a gente desconfia de todo mundo né.

$P$ - Mas, porque desconfia de todo mundo?

$\mathrm{R}$ - Porque na academia a gente tem uma impressão um pouco deturpada da tropa.

$P$ - Qual é a impressão que se tem da tropa?

$\mathrm{R}$ - Que tem muito ladrão, que tem muita gente indisciplinada.

P - E como é que você tem essa impressão? São os oficiais que dizem isso? Você olha e acha isso?

$\mathrm{R}$ - A gente quando entra na Polícia Militar mesmo, a gente já vem com essa impressão, com esse estereótipo.

[...]

P - Pois é. E aí a sua tropa faz do jeito que você aprendeu ou eles aprenderam diferente e fazem assim?

$\mathrm{R}$ - Não. Alguns fazem diferente. A maioria faz diferente. Até mesmo algumas incursões noturnas aí, a gente vê muitas coisas erradas, alguns procedimentos errados porque uns saem pra um lado, outros saem pro outro. Não usam bastante a técnica.

$P$ - E quando você vê o pessoal fazer diferente, você vê que tá errado?

$R$ - Depois eu chamo a atenção e mostro o certo como é pra fazer.

P - E aí, quando você mostra o certo, chama a atenção, na próxima vez eles assimilam aquilo que você passou ou voltam a fazer tudo da mesma forma que estavam fazendo antes?

$\mathrm{R}$ - Voltam a fazer igual como estavam fazendo. Tem que ser algo assim que é cons-

\footnotetext{
${ }^{5}$ Novinho não é somente um termo que denota inexperiência, mas, sobretudo, quer dizer aquele que ainda está em teste de confiança. Para se integrar é preciso, em todos os sentidos, ganhar a confiança dos antigões.
}

Planeta Amazônia: Revista Internacional de Direito Ambiental e Políticas Públicas 
tante. (Tenente com 5 anos de serviço)

Nessa fala, podemos observar que o estigma, construído em torno das organizações policiais, também se reproduz na formação dos oficiais, a elite da organização. Uma observação contundente dessa imagem é que, embora o oficial, diga que a academia é responsável por passar uma impressão deturpada da tropa, ele reafirma a visão que ele retira da sua própria experiência no comando, destacando que: agente vê muitas coisas erradas e que mesmo diante das instruções, dizendo qual é o certo, como é pra fazer, assimilam, mas continuam praticando formas ilegais de policiamento.

Assim, o oficial já tem a visão de que os policiais, especialmente os praças, são ladrões e indisciplinados e, por isso, precisam ser tratados com desconfiança. Aqui, aparece claramente a pedagogia da suspeita ${ }^{6}$ atuando para dentro, dos oficiais em relação aos praças. M as esta situação, também, vem corroborar um estigma da população em relação aos policiais. A impressão que a sociedade tem é de que na instituição existem muitos ladrões. Esta é, portanto, a suspeita funcionando de fora da polícia para dentro, que se contrapõe à suspeita do policial em relação ao cidadão.

Além disso, ainda tem uma questão mais grave: a forma de atuação diferenciada, visto que os antigões, em geral, no passado já aprenderam a trabalhar com outros antigões que não possuíam o conhecimento técnico de atuação e também "aprenderam na prática" e assim repassaram aos que vieram depois. Diante deste quadro, esvanece qualquer doutrina ou teoria de polícia. Prevalece a construção de uma prática de policiamento nos estertores da legalidade e a construção de uma identidade baseada no silêncio.

\section{A INCORPORAÇÃO DOS PRAÇAS E AS AMBIGUIDADES DA LEALDADE DIANTE DOS ESQUEM AS}

Um sentimento de desconfiança, a possibilidade de conflitos toma conta de uma unidade de policiamento quando da incorporação ao trabalho de novos policiais. Este sentimento aparece porque 0 veterano, 0 antigão, que já vem presenciando esses momentos por diversas vezes, sabe que o novinho é portador de conhecimentos, que certamente irá entrar em conflito com velhas práticas cotidianas. Embora sabendo que isso não vai alterar profundamente a realidade, a presença de estranhos pode representar certo incômodo aos esquemas já praticados durante o policiamento (MIRANDA, 2009).

Apesar dessa ameaça representada pelos novos policiais, as fragilidades deles aparecem frente à cultura organizacional, à força da prática policial e ao prestígio dos policiais antigões na instituição, especialmente no policiamento ostensivo das ruas, onde as disputas

\footnotetext{
${ }^{6}$ A pedagogia da suspeita é um estigma que é depurado nos treinamentos. A atuação policial está constituída numa visão de que a sociedade é composta de uma divisão entre pessoas de bem e bandidos e que cabe ao policial militar identificar e separar as pessoas pertencentes a estes dois universos, de modo a proteger as pessoas de bem dos bandidos, objetivando prevenir e/ ou reprimir o cometimento de crimes e preservar a ordem pública, cumprindo sua missão constitucional.
}

Planeta Amazônia: Revista Internacional de Direito Ambiental e Políticas Públicas 
políticas mais gerais são realizadas e onde os veteranos têm mais espaço para buscar deteriorar os saberes específicos e os valores morais e éticos adquiridos no processo de formação.

$\mathrm{Na}$ busca de se inserir no universo policial e construir sua identidade profissional, o policial advindo do curso de formação vai se deparar com uma cultura organizacional resistente a mudanças. Novas formas de pensar e de agir provocam a desconfiança dos antigões, põem em questão o seu posicionamento frente à prática policial. Diante deste cenário, o novo policial tende a agir de três maneiras distintas: a) adapta-se à forma de atuação dos mais antigos com os quais vai trabalhar e abandona os conhecimentos adquiridos durante 0 curso de formação; b) ignora o conhecimento prático do policial mais antigo e passa a atuar utilizando como parâmetro os conhecimentos do curso; e c) alia o conhecimento adquirido no curso ao conhecimento prático do mais antigo, utilizando para tal uma avaliação de ambos os conhecimentos postos à sua disposição, tendo como parâmetro o tipo de policial que deseja tornarse, como no exemplo abaixo:

Bem, na verdade, eu não sou totalmente a favor e nem totalmente contra o que dizem os mais antigos, mas eu tenho que dosar. Espera aí! Eu não posso levar em consideração tudo o que falaram na escola e nem posso levar em consideração tudo o que a pessoa tá me falando aqui porque ele é mais experiente do que eu na polícia. Eu tenho que ter um pouco de bom senso. Até que ponto aquela formação escolar policial militar é significativa pra mim? E até que ponto a experiência desse profissional, desse policial que tem muito mais tempo do que eu na polícia, é relevante pra mim? Então, espera aí. Eu tenho que pegar um pouco. Eu tenho que saber ser críticoreflexivo. Eu pego um pouco do que a formação me disse e um pouco do que esse profissional que também tem experiência e também é pertinente tá me dizendo e somar. E não só me entregar à formação da escola e não também deixar de levar em consideração o que ele tá me falando, mas ter, somar as forças e pegar tudo o que me trouxeram. Pegar uma peneira, botar na peneira e o que ela peneirar, aí sim é significativo né. Absorver um pouco do que dá a formação da escola e absorver um pouco da experiência do que aquele profissional tá me dizendo. (Soldado com 5 anos de serviço)

No caso dos policiais novatos, nos primeiros serviços, dependendo da equipe com a qual irão trabalhar, eles não terão chance de colocar em prática os conhecimentos do curso porque os veteranos não permitirão que isso aconteça. Primeiro porque os novinhos estarão sempre sob as ordens dos antigões, salvo exceções. Segundo, porque, mesmo se estiverem trabalhando nas guarnições das viaturas, a eles serão destinadas apenas as atividades mais triviais, como, por exemplo, numa perseguição a pé, tomar conta da viatura ou, ainda, fazer a segurança da equipe por ocasião de uma abordagem. Se em algum momento houver a possibilidade de ultrapassar o saber fazer cotidiano dos veteranos é porque o novinho já estará em posição superior, mas aí já estão sendo reproduzidos velhos vícios e práticas ilegais de policiamento, é a incorporação na rede, já é um de dentro.

De acordo com Muniz (2001), o serviço policial constrói redes de relações tecidas pela ótica da cooperação entre os integrantes do grupo que trabalha junto (denominada na Polícia Militar como Guarnição de Serviço ou GU), sendo estabelecida a lógica do me ajuda que te

Planeta Amazônia: Revista Internacional de Direito Ambiental e Políticas Públicas 
ajudo. Essa norma informal é uma das chaves para o novinho barganhar seu ingresso no grupo. É dessa forma que uma rede de sociabilidade entre policiais e colaboradores é formada.

A autora afirma que, aos poucos, um jovem policial aprende que, para fazer o seu trabalho, tem que atender a outras carências, e ampliar a sua rede de conhecidos e colaboradores que podem quebrar um galho, oferecendo passagens gratuitas em coletivos, fazendo pequenos consertos de lanternagem e mecânica, completando o combustível da viatura ou do carro particular. Ao aderir a essas normas informais que regem o cotidiano dos policiais, estes as legitimam ${ }^{8}$ e passam a deixar de lado as leis e as normas formalmente estabelecidas pelo Estado. É por essa razão que alguns tenentes evitam organizar uma guarnição integrada por policiais antigos e novos, conforme afirma este entrevistado:

[...] Então, o que acontece? Muitas das vezes, muitas das vezes é, você prefere colocar três novinhos que você sabe que são inexperientes, mas sempre coloca é na... sempre coloca à disposição, sempre tá passando na fiscalização, do que botar com um antigão e esse antigão já passar, já incutir valores negativos, já nos novinhos, entendeu? A gente sabe que um policial quando novo, muitas das vezes, é mais fácil de ser vulnerável à situação. (Tenente com 2 anos de serviço)

A noção de confiança se estabelece num quadro de profunda ambiguidade. Os antigões, detentores de práticas cotidianas, do conhecimento sobre o funcionamento da dinâmica das ruas, isto é, os portadores do saber-poder (FOUCAULT, 1999), submetem os novinhos, ainda inexperientes e desprovidos das informações necessárias dessa dinâmica, a uma expectativa de corresponder ao serviço e aos esquemas incorporados por essa dinâmica. Neste momento, sua atuação será o elemento decisivo para sua incorporação nas equipes.

Estas equipes já estabelecidas utilizam esse tipo de subterfúgio, o saber-poder das ruas para garantir vantagens para si por intermédio de atos nem sempre lícitos. Na verdade, alguns atos são ilegais, na medida em que os policiais se envolvem em esquemas criminosos, tais como: pegar propina em boca de fumo, forjar provas contra pessoas suspeitas, se apropriar de bens e dinheiro encontrados em poder de ladrões, se apropriar de entorpecentes apreendidos em operações etc.

O novinho vai aprender que a rede de colaboradores citada por M uniz (2001) pode ser bem extensa e envolver diversos tipos e níveis de relação, dependendo da criatividade das equipes, da participação ou não do oficial interativo e do que a equipe está disposta a fazer para ganhar dinheiro ou outras vantagens.

Nos primeiros serviços, nem mesmo da partilha da catação o policial novato tomará conhecimento. Algumas informações de pouca importância Ihe serão repassadas para testar

\footnotetext{
${ }^{7}$ A sociabilidade é o meio pelo qual as pessoas (independente de classe social) se relacionam entre si de modo a gerar maior interação entre elas e, consequentemente, contribuírem umas com as outras para uma vida harmônica e até a resolução ou felizmente a não propagação de problemas pessoais (D'INCAO, 1994).

${ }^{8}$ De acordo com Correa (2009), o termo legitimidade possui dois significados: um genérico e um específico. Aqui será utilizado apenas o significado genérico. Segundo essa acepção, legitimidade pode ser definida como sendo um atributo do Estado que consiste na presença, em uma parcela significativa da população, de um grau de consenso capaz de assegurar a obediência sem a necessidade de recorrer ao uso da força, a não ser em casos esporádicos.
}

Planeta Amazônia: Revista Internacional de Direito Ambiental e Políticas Públicas 
se é confiável ou não e, à medida que for assimilando ou não a filosofia do grupo, poderá tomar parte nas ações de maior importância, responsabilidade e/ou sigilo.

Em relação à catação ${ }^{9}, 0$ modo de catar mais utilizado pelos policiais é o estabelecimento de coitas, geralmente semanais, para intensificar as rondas em determinadas áreas. 0 comandante da guarnição ou algum dos componentes, que já conhece o empresário ou que se dispõe a estabelecer a relação de amizade, vai até o ponto comercial e oferece os serviços da guarnição, ou ainda é chamado pelo proprietário, que lhe fará uma proposta para que sejam feitas rondas mais frequentes às proximidades do seu negócio.

Vale salientar que, a rigor, não é o policial que obriga o dono do bar, da padaria ou do mercadinho a lhe dar dinheiro. É o comerciante que faz questão de dar dinheiro para que 0 policial se comprometa a fazer a ronda na rua em que seu ponto comercial está localizado. A catação funciona, portanto, como uma via de mão dupla: tanto o policial quer comprometer o comerciante com o pagamento do acerto, quanto o comerciante quer comprometer o policial com a realização da ronda.

Então, o proprietário da lanchonete fornece o lanche noturno, o dono da padaria fornece o pão para o café da manhã, o proprietário do restaurante fornece almoço, o gerente do posto de combustível, um valor pecuniário e, assim por diante, criando uma rotina de rondas periódicas e, portanto, mais segurança para a rua, o quarteirão, o bairro.

0 acerto não é realizado apenas com uma das guarnições da área em virtude de que esta, sozinha, não teria como garantir a segurança em tempo integral, tendo em vista que a escala é o seguinte: turno de trabalho de 12 horas e folga de 24 horas e turno de trabalho de 24 horas e folga de 48 horas. Então, para que funcione adequadamente, é necessária a concordância de todas as equipes que atuam na área. Desse modo, cada equipe recebe a cota uma vez por mês.

Nem sempre todas as equipes aceitam o acordo. Nesse caso, pode acontecer de um dos integrantes da equipe aceitar, ou a equipe não atrapalhar o acordo, deixando, no entanto, de receber o acerto, que será repassado para as demais pelo patrão.

Embora a lei do silêncio seja a regra geral, é, também, uma necessidade forçada à incorporação nos esquemas. Existem casos em que policiais mais cuidadosos não concordam com certo modo de atuação dos antigões, esses policiais normalmente solicitam trocar de equipes, sair da viatura, conforme podemos observar abaixo pelas afirmações do tenente que atua como oficial interativo de uma Zona de Policiamento:

\footnotetext{
${ }^{9}$ Para Bretas 1997), há dois tipos de corrupção policial: um deles é a prática do suborno, feita por muita gente, que dá um presentinho ao policial, quando comete uma infração de trânsito ou algo parecido. No caso da polícia do Pará, o mais comum é que o policial receba presentinhos para fazer a segurança do ponto comercial de algum empresário, como donos de supermercado, farmácia, posto de gasolina etc. Evidentemente, nao estamos falando das coisas, dos objetos que o policial recebe de forma gratuita, visto que o fato de um policial aceitar um café, um refreigerante (coca-cola) ou outro bem ou serviço pelo qual normalmente deveria pagar não constitui em si um fato ilícito, mas poderá vir a tornar-se um ato de corrupção se essa gratuidade gera algum tipo de compromisso com seu provedor. Não abordaremos neste trabalho a corrupção administrativa, isto é, que diz respeito àquelas condutas no nível da gestão de recursos humanos e materiais no interior da instituição e que são semelhantes àquelas presentes em outros órgãos públicos (pagamento por promoção ou aprovação em concursos internos, desvio de fundos, pagamento por liberação das escalas de serviços, entre outras).
}

Planeta Amazônia: Revista Internacional de Direito Ambiental e Políticas Públicas 
E aí, muitas das vezes, chegam alguns policiais que chegam: "Porra, chefe, me tire da viatura". A gente não sabia o porquê. "Não, me tire da viatura, pelo amor de Deus, que eu não vejo a hora de ser autuado em flagrante por uma guarnição da Corregedoria porque o Fulano de Tal, o Ciclano vai em 'boca de fumo' e coisa do tipo". Então, eu sei que pra eles é mais difícil. (Tenente com 5 anos de serviço)

M esmo trabalhando em uma função privilegiada como a viatura, o policial fica sempre receoso de ser autuado em flagrante por uma guarnição da Corregedoria por causa do policial que aposta na impunidade e vai em boca de fumo, não para prender os traficantes, mas para pegar propina. Em outros casos, sobretudo, o novinho permanece trabalhando com a guarnição sem denunciar ao oficial os policiais envolvidos nos esquemas, porque, além de ele correr o risco de se envolver sem tirar proveito algum, ele vai ferir os códigos subjacentes ou submersos da prática de policiamento, especialmente na periferia da cidade.

À medida que o tempo vai passando, os policiais novatos vão se inserindo nas equipes que mais se adéquam a suas aspirações ou vão se amoldando ao sistema já existente, participando ativamente ou fazendo vista grossa para os esquemas, para poderem ser aceitos e tornarem-se confiáveis aos olhos dos antigões e da tropa em geral.

A tentativa do policial novato em realizar suas tarefas de acordo com os seus valores morais e éticos e com os saberes adquiridos no curso de formação é fragilizada em função da profunda valorização dada aos saberes do cotidiano e àquilo que vem sendo praticado tradicionalmente. Neste processo, as condutas legais se tornam ambíguas, pois o discurso para justificativa de não seguir as doutrinas está sustentado pela restrição e pela ausência de recursos técnico-científicos no aparelho policial.

$P$ - E voê acha que o "novinho" hoje escuta o conselho do mais antigo ou ele já chega achando que o "antigão", como faz tempo que fez curso, não sabe muito das coisas?

$\mathrm{R}$ - Geralmente, ele acha que sabe, né, mas geralmente não sabe. Ele geralmente escuta porque tem que é... com a experiência, ele tem que se adequar à situação porque você vai na rua, é uma situação diferente, abordar cidadão, deter cidadão, é, ainda continua, como aqui acontece, ainda continua. (Cabo com 22 anos de serviço)

Como se observa, os policiais antigões acreditam ainda que os conhecimentos técnicos adquiridos no curso não são aplicáveis à prática cotidiana e procuram deteriorar tais conhecimentos, para reforçar as suas próprias práticas de atuação. Miranda (2009), se referindo aos policiais civis, afirma que um dos instrumentos utilizados pelos policiais veteranos para tentar deteriorar os conhecimentos e os valores dos novinhos é o sistema de sanções positivas e/ou negativas que funcionam para mensurar o grau de aceitação das regras estabelecidas. No caso dos policiais militares, estas sanções se traduzem da seguinte forma: prêmios materiais e/ ou simbólicos.

O prêmio de caráter material se traduz, quase sempre, na distribuição de propinas e de presentes entre os policiais da equipe (cesta básica recebida do patrão, por exemplo). 0 prêmio, de cunho simbólico, manifesta-se na alocação de pessoal, expressa sistematicamente no deslocamento de uma função para outra, isto é, mudança do policiamento a pé para o polici- 
amento motorizado em motocicleta ou viatura, para outro posto de serviço melhor. Por sua vez, as sanções negativas revelam-se em punições diversas e em alocações ruins, tais como deslocamento para a guarda do quartel, para o policiamento a pé ou mesmo para o Destacamento Especial de Polícia Comunitária (DEPC) ou Posto Avançado de Polícia Comunitária (PAPC).

\section{A CONFIANÇA COMO CRITÉRIO DE ACEITAÇÃO}

Para pertencer a uma equipe, principalmente, para ser reconhecido como membro desta, é importante guardar lealdade ao grupo e comprometer-se com sua dinâmica. Nesse contexto, estão determinados os padrões submersos e as normas de conduta sobre alguns aspectos do trabalho policial, que são distintos das normas e dos regulamentos oficiais, que devem ser seguidos pelos membros para que haja a sua plena incorporação. Assim, o conjunto de medidas para recompensa e/ou punição de policiais e o seu encaminhamento nas unidades policiais é fartamente sinalizado.

Mingardi (1992 p.171), ao realizar estudo sobre a Polícia Civil de São Paulo, corrobora as afirmações de Miranda (2009) afirmando que é instituído no distrito um processo de aprendizagem, no qual os policiais novatos deterioram os seus valores, ou seja, "é no distrito policial que policiais antigos instruem os novos policiais e sempre dentro da norma vigente. Não há duvida de que isso ajuda a transferir para os 'novinhos' as ideias que norteiam os veteranos".

A mesma lógica é aplicada a Polícia M ilitar. É no policiamento ostensivo de rua que os antigões vão tentar impor a sua forma de atuação aos novinhos. Estes precisam ser habilidosos para tentar driblar as práticas tradicionais e cotidianas de policiamento e tentar fazer valer para a equipe estratégias técnicas e legais de atuação. Alguns comandantes de guarnição até aceitam sugestões quanto aos novos conhecimentos, mas a grande maioria não aceita modificar sua forma de trabalhar e, dependendo de como age o novinho, dificultam a sua ambientação na guarnição, conforme afirma a fala a seguir:

$P$ - E como é chegar "novinho" pra ir trabalhar num lugar onde todo mundo já tem as suas equipes? É difícil de ser aceito?

$\mathrm{R}$ - É difícil, sinceramente. Geralmente, é difícil.

$P$ - E como foi que você conseguiu se inserir no grupo?

$R$ - Aos poucos, aos poucos, tentando se entrosar aos poucos, pegando confiança.

$P$ - E como é que pega confiança?

$\mathrm{R}$ - Tem que se adequar a algumas coisas que... algumas até obscuras. (Cabo com 22 anos de serviço).

Conforme se constata, nos grupos previamente formados pelos veteranos já há critérios, normas e códigos estabelecidos, as quais o novinho precisará apreender, obedecer e respeitar para ser aceito como membro. Dentre esses critérios, um dos mais importantes é a 
confiança $^{10}$. 0 que impera no cotidiano da polícia não é a obediência, a hierarquia, a disciplina e sim a confiança estabelecida entre os companheiros de trabalho.

No policiamento ostensivo, conforme se pode observar na unidade operacional que serviu de base para a pesquisa, onde se encontram policiais atuando nos postos de serviço, nas rondas tiradas nas viaturas operacionais, nas equipes dos DEPC, PAPC e nas guarnições dos oficiais interativos, o princípio que rege e sustenta as relações sociais entre os policiais está assentado na confiança pessoal e profissional.

As regras que regem estas relações são legitimadas pelo estatuto de uma honra que se pauta na confiança, na fidelidade entre os companheiros de serviço. Nesse contexto, mais do que a hierarquia e a disciplina, que, teoricamente, são os pilares da organização policial militar, a confiança no sentido da cumplicidade pessoal é o esteio submerso do sentimento de pertença, da identidade.

A confiança que um policial deposita no outro perpassa também pelo aspecto técnicooperacional. 0 integrante de uma equipe (guarnição) precisa ser, pelo menos, operacionalmente confiável. Para isso, é necessário que o policial saiba o que fazer em uma ocorrência, sendo ela de qualquer natureza (agressão, furto, roubo, assalto com refém, tráfico de drogas, homicídio, dentre muitos). Conforme se pode destacar da fala a seguir, é necessário que 0 companheiro seja operacional:

É uma leitura assim muito aprofundada devido à situação. Por exemplo, qual a situação, como eu posso confiar no Cabo Tal operacionalmente ou na pessoa dele? Por exemplo, eu posso confiar no Cabo Tal que se, o Cabo Tal é um policial bandido, um exemplo né. Eu e o Cabo Tal estamos numa ocorrência, então o Cabo Tal é operacional né. Ele tá no meu nível operacional. Aí a gente vai, troca tiro, prende, aborda, baleia, mata se for 0 caso, beleza. Eu posso confiar que ele não vai me deixar na mão, usando um termo mais esdrúxulo, ele não vai 'afroxar', né. Ele tá no meu nível operacional. Se lá na frente, numa ocorrência, nós topamos com um parceiro de bandidagem do Cabo Tal? Operacionalmente ele é confiável. E na segunda hipótese? Entendeu? Então, é uma leitura muito aprofundada pra mim falar superficialmente assim do Cabo Tal. Eu posso confiar no Cabo Tal? São vários níveis de confiança: confiança operacional, confiança pessoal. Como eu digo sempre, olhe, a Polícia Militar ela tem dois títulos: ela é a pior e a melhor. Justifico: nem uma polícia quer fazer o serviço da Polícia Militar; outros policiais federais, civis, guardas municipais, guardas metropolitanos; não entram de dois onde nós entramos; não ficam em destacamentos à beira da estrada num destacamento entre Itupiranga e M arabá, de madeira, ganhando os salários que nós ganhamos, entendeu? Ela é melhor por essa bravura, por essa força; mas ela é a pior pela mazela, pelos desvios de conduta, pelos desvios de dinheiro, pelos desvios de rancho, pelos desvios de combustível, pelas péssimas condições de trabalho, pelo despreparo de muitos, e por aquela situação mais simples: aquele soldado chega passadinho, fardadinho, no horário: "bom dia, tenente. Tudo bom com o senhor?". Sexta-feira vai embora. Se o senhor espirrar no final de semana, 'saúde'. Ele, operacionalmente, não é confiável. (Cabo com 12 anos de serviço)

\footnotetext{
${ }^{10}$ Será aqui adotado o conceito de confiança exposto por Newell e Swan (2000), que a definem como um conjunto de expectativas compartilhadas por pessoas, grupos ou firmas, com base na reciprocidade e boa vontade, expectativas estas influenciadas pelo contexto institucional.
}

Planeta Amazônia: Revista Internacional de Direito Ambiental e Políticas Públicas 
$\mathrm{Na}$ fala deste policial, é possível identificar dois momentos que marcam profundamente a acarreia profissional e o imaginário em torno da instituição. No primeiro momento, ele destaca a bravura como a marca do operacional. Nesse contexto, veladamente ele quer deixar bem claro que policial de verdade é aquele que atua na rua e não os que atuam na parte administrativa, nos quartéis, aqui vistos como o passadinho, fardadinho e que em caso de espirrar deseja "saúde" antecipadamente para o superior, este é inconfiável.

No segundo, há uma análise, ainda que de forma rude, mas que expressa a profunda ambivalência que constitui o cerne desta organização de poder burocrática. Este fala de dois lados que constituem essa instituição: de um, a bravura, a falta de equipamentos, salários indignos e até a falta de organização racional para cumprir a missão de oferecer segurança à população; e, de outro, quando se reporta às mazelas, exteriorizadas nos atos ilícitos. E, por fim, chama atenção para a confiança, e entre os destaques está o policial bandido, certamente a fonte de risco mais certa para os que atuam na parte operacional.

0 estabelecimento da confiança entre antigões e novinhos, ao mesmo tempo em que favorece a sociabilidade comunitária é positiva, também pode criar laços de corporativismo negativo. Muitos policiais, sejam antigões, ou novinhos, chegam a encobrir crimes ou transgressões disciplinares dos colegas de guarnição em nome da camaradagem e do código submerso de confiança existente entre os membros.

Quando são instaurados procedimentos administrativos para a apuração de crimes e/ ou transgressões disciplinares, é possível observar a tentativa ou o acobertamento de tais atos pelos colegas. Quando estes são ouvidos como testemunhas, não sendo necessário que estejam envolvidos, mas que sejam colegas de guarnição ou de turma de serviço ou simplesmente por serem colegas de farda, fala mais alto o código de conduta estabelecido à margem do legalmente vigente. Um dos cabos entrevistados relata uma situação em que ele acobertou diversas situações ilícitas referentes a uma ocorrência em que se envolveu com um colega de equipe, a fim de não entregar o policial:

Num final de semana, ele tava de folga e o cabo Tal assumiu o posto totalmente embriagado. Ele disse: "Olha, quem quiser trabalhar com quem pode se juntar e ir pra onde quiser" [...]. Aí sobrou só o Soldado Fulano de Tal que tava tão embriagado que não teve, soldado novinho já tava embriagado, um mês de formado e já não tinha nem condições de falar nada. [...] Aí veio um casal: "Olha, o Boxel deu um soco na cara dum menino aí". Aí, lá vem o menino, catorze anos, mas todo entroncado de tanto carregar açaí na costa, todo ensanguentado. [...] Aí o Soldado Fulano de Tal: "É, bora lá. Bora lá ver se ele é brabo mesmo". [...] Ele falou: "É tu que é o Fulano é?". "É, sou eu". "Por que tu bateu no cara?". Bateu no peito. "Por que tu bateu no cara?". Aí o cara baixinho, mas olha, torão. "Ei, não faça isso. Olhe, eu lhe respeito. 0 senhor é uma autoridade. 0 senhor tem que me respeitar. Ele me bateu também". "Bate em mim aqui também". [...] E ele foi pra cima. E o cara era boxer. O soldado Fulano de Tal teve duas vantagens: o chute de coturno que pegou no joelho do cara, mas não foi uma coisa conectada. Ele deu uma bicuda e pegou e o cara amoleceu. [...]. Nisso, a pistola dele cai. Aí eu peguei a pistola [...] botei no cara de qualquer jeito. Segurei na calça. Aí ele: "Não, não. Eu vou". Aí o soldado Fulano de Tal levanta e dá-lhe na cara dele. Aí pronto. Não teve mais pistola que segurasse o homem. Ele foi pra cima do 
soldado Fulano de Tal e soco no soldado Fulano de Tal e eu puxando o cara. Aí o pessoal: "Ah, isso é covardia, dois contra um". Eu num tô batendo no cara. Eu tô só puxando o cara. Aí jogaram coco na gente, jogaram pedra. Aí teve um que veio com o terçado. Aí eu apontei nele, mas só que na hora do gatilho, aí eu botei pra cima: 'pou' (tiro). Aí espalhou todo mundo. Nisso que espalha todo mundo, ele corre. Aí o soldado Tal veio na minha: "Me dá minha arma, me dá minha arma". "Toma". Ele corre atrás do cara e dá-lhe dois na perna. As duas últimas munições. [...] Aí o coronel Tal ligou e tal. Aí quando foi à noite [...] o soldado X me falou: "Olha, eu tava dizendo pro coronel e ele falou que vai segurar a bronca. Ele não disse que ele errou né, mas pô, que só tinha novinho lá e tal". Esse soldado era "antigão" já. "Só tinha ‘novinho' desarmado. Ele só quer saber da arma". Eu digo: "A arma? Ah, ele quer a arma? Tava lá no chão, e eu peguei". "E de quem era? Do soldado Tal?". "Eu não sei te dizer". Eles tavam brigando, todos dois de camisa e de calça. Eu vou saber? Aí fomos pro inquérito né. Aí as testemunhas contra nós, todas embriagadas e tal e o investigador foi tirando uma, tirando outra, tirando outra. Aí o que aconteceu? O soldado Fulano de Tal pegou só trinta dias de prisão e eu não peguei nada. Entrei como testemunha dele né e até, sem querer me sobrepujar, salvador da situação da vida dele, né moleque que porra, e do emprego porque o que eu omiti. Eu realmente não disse: "Olhe, ele que chamou o cara pra porrada. Não. Aconteceu e tal e aí tinha um bom, apesar de não ter um bom, um pouquinho de conhecimento como eu tenho hoje, mas tinha a calma, a tranquilidade e eu fui tranquilo. Na hora da ocorrência e no inquérito, pra falar e pensar antes de responder as perguntas e acrescentar alguma coisa sempre pensando né, um pouquinho e tudo. Aí deu tudo certo, a gente saiu e tal. (Cabo no 6, com 12 anos de serviço)

Nessa situação em que o policial deveria, por obrigação legal, durante o Inquérito Policial M ilitar, relatar os fatos conforme aconteceram, juntamente com o outro policial envolvido, ele mentiu e omitiu diversas informações essenciais para a elucidação dos ilícitos cometidos por ambos. Nesse caso, eles sequer eram amigos, mas se uniram para se livrar das acusações que recaíam sobre seus ombros em virtude de uma ocorrência mal direcionada. 0 próprio comandante da unidade, reconhecido na Policia Militar como durão no sentido de não aceitar comportamentos desviantes, fez vista grossa para a situação porque também poderia ser responsabilizado por ter autorizado que fossem colocados somente policiais novatos em uma área em que a quantidade de ocorrências graves é alta.

No entanto, há o outro lado da moeda, a convivência próxima entre policiais também propicia a emergência de situações em que se ressaltam a competição, a mesquinhez, a dominação e as intrigas que potencializam, no momento em que reproduzem as dinâmicas relacionadas desta sociedade em que a honra - capital pessoal dos mais essenciais - é constantemente desafiada. Policiais com objetivo de se aproximar do chefe a todo custo se dispõem a denunciar pequenas falhas dos integrantes da equipe para aparecer positivamente. Começa assim o processo de derrubação entre os colegas e se estabelece um clima de desconfiança de uns em relação aos outros, conforme exemplificado na fala abaixo:

Olha, vamos supor aquele negócio que eu disse ainda agora né, entendeu? Olha bem, tá nós três trabalhando aqui. Tá normal. Pra mim me engrandecer na costa dos dois 
aqui eu vou ser aquele puxa-saco dele. Tudo o que acontecer, eu vou ter que participar pra ele, tá entendendo? Aí o que acontece? O pessoal vão ficar menosprezado e eu vou me engrandecer. 0 que eu pedir pra ele ali, possa ser que ele faça pra mim, entendeu? Uma falta de serviço, um atraso, tá entendendo? Aí ele já vai... tá entendendo? [...]. Sim, aí... eu tô aqui. Eu quero ganhar, entende, na costa do Cb Fulano. Aí eu chego: "Pô, tenente, olhe o Cb Fulano não tá aqui no Box. Ele já saiu pra ali. Chefe, será que ele não vai pedir alguma coisa?". Sabe por quê? Porque eu tô querendo me engrandecer nas costas dele. Então, tem muito isso no Batalhão. (Cabo no 4, com 19 anos de serviço)

Ao mesmo tempo em que o policial está entregando o colega que saiu pra ali, para fazer média com o chefe, para ter algum benefício, ele pode também estar preocupado com 0 que o policial foi fazer de errado ao sair pra ali. Como se conhecem há algum tempo, o policial tenta evitar que o colega se envolva em ilegalidades, quando vai a uma boca de fumo ou faz alguma outra coisa errada, que venha a comprometer toda a honra da instituição policial, caso ele seja descoberto.

Porque, no caso de alguém registrar por intermédio de filmagem ou denunciar uma irregularidade cometida por um policial, não é apenas o comportamento dele que será condenado, mas toda a instituição será prejudicada aos olhos da sociedade. Ainda é possível ver nesta análise, feita pelo policial, palavras que tentam esconder, mas que expõem a prática do subterfúgio como aquele negócio ou o silêncio na impossibilidade de encontrar a palavra adequada para não se expor e nem expor os demais.

\section{CONSIDERAÇÕES FINAIS}

A prática da catação é um ilícito carregado de ambivalências e que está subjacente à atuação do policial nas ruas, mas é comum um oficial ir a um estabelecimento comercial e receber a oferta de um presente. $E$, embora os policiais, em qualquer nível hierárquico, saibam que esta é uma prática ilegal, ela parece atender aos dois lados interessados nesta relação: para o policial, constitui renda extra, para os comerciantes em geral, seria a garantia de uma vigilância mais constante a preço baixo ou uma troca de favores.

É evidente que na sequência da própria atividade de policiamento que a catação subjaz numa estrutura que, certamente, fere os princípios burocráticos normais e legais da instituição policial. A capacidade dessa estrutura se reproduzir está na sua força de sublimar conhecimentos técnicos e forçar a adesão dos que se incorporam à atividade como uma espécie de ritual de passagem separando os que aceitam, dobrando os espíritos vulneráveis e afastando os que resistem.

Seria esta uma cultura policial subjacente? Um vício que se naturalizou e todos tendem a achar normal presentear alguém porque cumpriu o seu dever, neste caso, proteger a sociedade de atividades criminosas? Os elementos analisados poderiam até nos levar a essas conclusões, mas as informações tiradas muito mais do silêncio do entrevistado, dos intervalos provocados pela procura de uma palavra sem comprometimento, da pura interjeição, do gesto de baixar a cabeça, não nos permite adentrar mais profundamente no que pensa efetiva-

Planeta Amazônia: Revista Internacional de Direito Ambiental e Políticas Públicas 
mente sobre o tema.

Ao adentrar nas equipes, o policial, seja oficial, seja praça, não irá pôr em prática os conhecimentos técnicos, não é o profissionalismo que irá marcar sua passagem, será batizado ou entronizado a partir do respeito ao código de confiança, do silêncio. É preciso ser operacional. Essa frase quer dizer muito mais do que atuação policial, ela funciona como um divisor entre os que enfrentam a dinâmica das ruas e os que se escondem por detrás do manto da burocracia administrativa. Mas, também, quer dizer encarar o que for necessário, atuar para esconder ilícitos sob o véu do corporativismo, mesmo que isso venha a ferir o princípio da fé pública que se posta na atividade policial.

Por todas essas razões, e para não fugir da questão sociológica, a catação é uma prática que mantém vínculos estreitos com a cultura política do patrimonialismo que resiste sobre a ordem política moderna brasileira, mas seus mecanismos de reprodução e de verticalização se valem de atitudes cotidianas envoltos em uma fina camada superficial da modernidade. Provavelmente, se pode tirar daí o seu caráter ambivalente, pois tudo funciona com uma aparência legal ou aparentemente ingênua.

\section{REFERÊNCIAS}

BRETAS, M. L. Observações sobre a falência dos modelos policiais. Tempo Social, v.9, n.1, p.79-94, 1997.

CARUSO, Haydée Glória Cruz. Das práticas e dos seus saberes: A construção do "fazer policial" entre as praças da PMERJ. Dissertação de Mestrado em Antropologia. Programa de PósGraduação em Antropologia e Ciência Política. ICHF. Universidade Federal Fluminense. Niterói, 2004.

MINGARDI, Guaracy. Tiras Gansos e Trutas: cotidiano e reforma na polícia civil. São Paulo: Página Aberta, 1992.

MIRANDA, José da Cruz Bispo de. 0 outro aprendizado policial: ambiguidade ou sobre determinação entre rua e academia. Acessado no site: http://www.ufpi.br/mesteduc/eventos/ iiencontro/GT-5/GT-05-09.htm.

MUNIZ, Jaqueline. A Crise de Identidade das Polícias M ilitares Brasileiras: Dilemas e Paradoxos da Formação Educacional. Research and Education in Defense and Security Studies. Washington DC. May, 22-25, 2001.

NEWBURN, Tim. Understanding and preventing police corruption: lessons from the literature. In: Police Research Series Paper 11 0. Home Office, Policing and Reducing Crime Unit, 1999.

NEWELL S. e SWAN J. Trust and inter-Organization networking [Artigo] // Human Relations. Vol.10. 2000. p.1287-1328.

OLIVEIRA NETO, Sandoval Bittencourt de. Vinho Velho em Odres Novos: Uma análise da experiência de integração da segurança pública no Pará (1995-2004). Rio de Janeiro: UFRJ/ IFCS, 2004. (Dissertação de Mestrado)

URUEÑA, Nubia. La corrupción en la policía. Modalidades, causas y control. In: Policía, sociedad y estado: modernización y reforma policial en América del Sur. Frühling, $\mathrm{H}$ y Candina, $\mathrm{A}$, 
Editores. Centro de Estudios para el Desarrollo, 2001 p.107- 131.

Artigo recebido em 30 de janeiro de 2017.

Aprovado em 07 de fevereiro de 2017. 